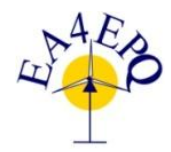

International Conference on Renewable Energies and Power Quality (ICREPQ'13)

Bilbao (Spain), $20^{\text {th }}$ to $22^{\text {th }}$ March, 2013

Renewable Energy and Pourer Qualing. Tournal (RE\&PQJ)

ISSN 2172-038 X, No.11, March 2013

\title{
Renewable Energy Policy and Legitimacy: a Developing Country Case
} Juan L. Espinoza ${ }^{1}$ and Edgar A. Barragán ${ }^{2}$

\author{
${ }^{1}$ Department of Electrical Engineering, Faculty of Engineering, University of Cuenca \\ Av. 12 de Abril s/n Cuenca (Ecuador) \\ Phone: 593-74051000, email: juan.espinoza@ucuenca.edu.ec \\ ${ }^{2}$ Faculty of Engineering, Universidad Politécnica Salesiana \\ Calle Vieja 12-30 y Elia Liut, Cuenca (Ecuador) \\ Phone: 593-72862213, email: tono_barragan@yahoo.es
}

\begin{abstract}
This paper analyzes some policies to promote renewable energy technologies in order to level the playing field in the energy sector. It is argued that although there are several energy policy options to be considered, their successful implementation depends on specific market and institutional contexts in any given country. Ecuador's electricity sector is presented as a case study. By extending the concept of industry legitimacy this study makes contributions to institutional and strategic change theories. The Ecuadorian case has important implications for policy makers and energy managers because it shows how a renewable energy industry can be developed in a regulated electricity market.
\end{abstract}

\section{Keywords}

Renewable energy policy, sustainability, institutional factors, legitimacy, Ecuador.

\section{Introduction}

The energy sector, a key component of economic development, can be also a source of social and environmental conflict. Clean energy or renewable energy (RE) technologies - such as wind power, solar, small hydropower, and biomass - are currently considered alternatives in the shift toward sustainability in the energy sector as they contribute to the energy supply with minimal environmental impact ([1], [2]).

However, most RE(s) continue to play a modest role in the global energy matrix due to their high production costs when compared to conventional technologies using fossil fuels. This is mostly because the current energy cost considerations do not take environmental externalities into account. In addition, RE technologies face an institutional barrier that is reflected in the existing economic and market infrastructure that seems to favor the conventional energy sector ([1]).

Through the analysis of four in-depth case studies of the emergence of renewable energy industries (wind power) in two industrialized and two emerging economies, Espinoza and Vredenburg (2010) built a model for sustainable energy industry development. The model demonstrated that fundamental economic indicators are insufficient when explaining new industry development. Environmental, sociocultural and institutional factors idiosyncratic to individual jurisdictions seem to play important roles in the emergence of renewable energy industries. Specifically, the model identified seven factors (grouped into three categories) that explain the emergence of the wind power industry: 1) Macro economic factors (state of the economy and established related industries); 2) Project specific factors (economic component, natural capital and social capital); 3) Institutional factors (formal and informal) (See Figure 1).

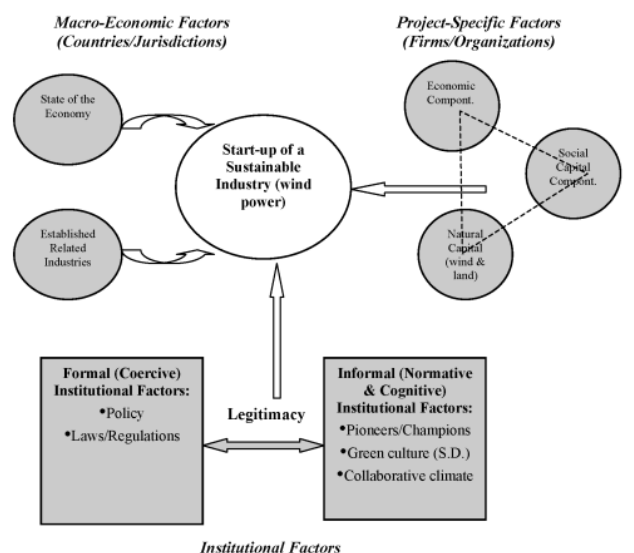

Fig. 1. Model of sustainable industry development [2] 


\section{Institutional Factors and Legitimacy}

The model developed by Espinoza and Vredenburg (2010) identified two types of institutional factors: formal and informal. This categorization relies on North's (1990) work that relates formal institutions to legal aspects (policies, laws and regulations) and informal institutions to cultural or "taken for granted" issues such as those identified in the model: jurisdiction-specific environmental commitment (e.g., "green culture"), or the role of champions and visionary leaders ("environmental entrepreneurs").

The model suggests that the dynamic interaction of both formal and informal institutional factors generates "industry legitimacy". Aldrich and Fiol (1994) argued that access to capital, markets, and governmental protection are all partially dependent on the level of legitimacy achieved by an emerging industry.

There are two dimensions of industry's legitimacy: 1) cognitive, or knowledge about the new activity to succeed in an industry; and 2) socio-political, or the value placed on an activity by cultural norms and political authorities ([3]). In contrast to competitive forces, institutional forces exert a relatively similar pressure on organizations to comply with institutional rules or practices in exchange for the conferral of legitimacy ([4]).

Suchman (1995) incorporates both the strategic dimension and the cognitive-institutional dimension to define legitimacy as "a generalized perception or assumption that the actions of an entity are desirable, proper, or appropriate within some socially constructed system of norms, values, beliefs, and definitions" ([5] p. 574).

\section{Objective}

This paper seeks to explain how formal institutional factors, related to government policy implementation, promote renewable energy development in a developing country. For that, the authors analyze Ecuador as the country case. Ecuador is located in northwestern Latin America; it has a population of 14 million people and is one of the principal oil producers in the region.

\section{Why is policy necessary to promote renewable energy?}

Two important factors justify the need for government participation, through energy policies, to make RE competitive in the energy market: 1) economically, markets are not perfect (there are imperfections ${ }^{1}$ and externalities ${ }^{2}$ to deal with) and 2) institutionally, renewables represent a different and opposite paradigm to the traditional model based on fossil-fuel exploitation and use: the current financial, organizational and institutional environment is not very well suited to RE acceptance ([1]).

There is abundant evidence that government intervention does not always reduce economic growth - and that in some cases it is needed to kick-start it ${ }^{3}$ ([6]). Ayres (2001) therefore suggested that the "business as usual" trajectory (i.e., locked in fossil fuels) is a dead end because it excludes any new technological direction. This new direction should be supported by government policy.

Many policies can be conceived to develop RE technologies and thus level the playing field in the energy sector. Clean energy policy can be divided into two broad categories: incentives and regulations. Incentives are policies that directly address economic and financial barriers to renewable energy and are, by definition, voluntary. Regulations are not voluntary policies and target non-economic barriers to clean energy development. However, the lines between incentives and regulations are not always clear. In fact, some of the most popular types of policy, such as feed-in tariffs ${ }^{4}$,

\footnotetext{
${ }^{1}$ The resulting price stability, environmental, and economic benefits (e.g. distributed generation) of RE resources accrue to the public at large rather than directly to the purchasing consumer ([8])

2 This point relates to environmental and social costs resulting from fossil-fuel use (i.e. estimated health effects). For instance, the ExternE study concluded that the higher the renewable contribution in the electricity system, the lower the social cost of the electricity produced ([9]).

${ }^{3}$ Examples include submarines, jet engines, radar, nuclear power and the Internet. Also, large hydroelectric dams that provide both irrigation and electricity to several important areas were initially government funded ([6])

${ }^{4}$ Feed-in Tariff policy has proved to be the most effective for wind power development ([10]). Case studies in Denmark, Germany and Spain confirm this argument.
} 
incorporate both regulations and incentives ([7]). In short, RE policies can fall into six general categories: taxes, incentives, regulation, mandatory goals for renewables, market instruments, and research and development.

\section{A. Taxes}

From the standpoint of economic efficiency, increasing taxes on fossil fuels are a good approach to reducing fossil-fuel consumption ([11], [6]). It would give energy consumers a clear price signal in order to change their consumption patterns in a more efficient manner by incorporating the environmental and social costs of energy use directly in energy prices.

\section{B. Financial incentives / subsidies}

To help RE projects get established it is essential to create financial incentives designed to lower the initial costs and perceived financial risks associated with RE technologies. In addition, the role of the government need not be restricted to regulation. Government purchases of a product (i.e. clean energy) in the early stages of an industry may tilt the balance in favor of the firms producing it ([12]).

\section{Regulation}

Energy producers should be required to take environmental costs into account when evaluating energy sources. Direct regulation to reduce pollution (air, water, and soil), product quality standards and/or limitations in the conditions and use of a product ([13]) could be used to encourage cleaner sources of energy.

\section{Mandatory goals for renewable}

Most governments have an explicit annual goal for renewable energy generation, as a percentage of total electricity generation. For instance, the US's Renewable Portfolio Standard describes this approach, which is distinguished by: 1) assigning responsibility for meeting the goal to a specific actor (i.e., users, retailers or generators); 2) Having a substantive penalty for failing to meet the goal ([14]).

\section{E. Market instruments (Green certificates)}

A green certificate is a market-based instrument based on recognizing that a $\mathrm{RE}$ source provides two products: electricity to the grid and environmental attributes (i.e. reduced $\mathrm{CO} 2$ emissions). These environmental attributes are represented by a green certificate to be traded on a secondary market ([14]).

\section{F. Research and Development}

Developing new technologies and ensuring their transfer to industry are key requirements for expanding the use of RE sources. Since renewable resources vary so widely by region, state and local efforts could play a useful role in advancing their development ([15]).

In conclusion, the choice of policy options depends less on their potential strengths (and weaknesses) than on pragmatic matters such as the ability to build a political consensus around the use of particular options ([13]). In addition, it is vital that policies be evaluated against a number of criteria such as effectiveness, cost and ease of implementation ([11]). It might also be important to use several options simultaneously.

\section{Renewable Energy Policy in Ecuador}

In developing countries such as Ecuador, the implementation of some renewable energy policies can be more complex than in developed nations. In addition to economic and technological limitations, Ecuador's electricity sector is a regulated market controlled by the government ${ }^{5}$ with minimal private participation and competition. While this situation can on first glance appear to be an obstacle to developing a renewable energy industry, in the Ecuadorian case it has acted as an incentive.

During the last few years Ecuador has shown political commitment to the development of RE sources. In July 2007 the Ministry of Electricity and Renewable Energy (MEER) was created. One of its main goals was to develop renewable energy sources $^{6}$ in order to move from a "conventional" situation toward a sustainable energy matrix by 2020 . The main objective of this energy policy was to change a $50 \%$ fossil fuel-based electricity matrix (in 2006) to a $95 \%$

\footnotetext{
${ }^{5}$ There is an established (fixed) price for each type of consumer (residential, commercial, industrial) as well as a centralized energy dispatch for power generators.

${ }^{6}$ They include both conventional (large hydropower) and non-conventional (solar, wind, geothermal, etc).
} 
renewable energy-based power matrix by 2020 (including 93\% large hydropower and 2\% nonconventional renewable energy: geothermal, photovoltaic, and wind power) ${ }^{7}$.

In addition, in 2008 a new Constitution was approved in which energy is considered as a strategic sector. The State (through MEER) is now responsible for all energy sector activities including planning, construction and operation of energy generation projects. Private participation is allowed in small-scale projects (below 50 MW).

Since then the Ecuadorian government has implemented several policies in order to accomplish its constitutional mandate. The objective seems to be clear: building legitimacy of the renewable energy industry.

Annex 1 identifies the main renewable energy policies implemented in Ecuador.

\section{Research and Results}

Using Delphi methodology, Barragán (2012) determined the importance of Espinoza and Vredenburg's (2010) seven factors that explain the start-up of a renewable energy industry. Research consisted on both face-to-face and email interviews with Ecuadorian experts ${ }^{8}$ in the renewable energy sector. These professionals were asked to rank the importance of the seven factors contributing to the development of the wind power industry in Ecuador from 1 to 10 (See Figure 2).

Figure 2 shows that Natural Capital, Informal Institutional Factors and Formal Institutional Factors ranked as the top three aspects contributing to the development of the wind power industry in Ecuador.

\footnotetext{
7 Only in 2011, as part of the government "energy revolution", eight large hydroelectric projects started their construction with a total power capacity of $2800 \mathrm{MW}$ (more than the current installed hydropower capacity in the country). In addition, a $16.5 \mathrm{MW}$ wind power project started its operation in January 2013 and studies for geothermal and photovoltaic projects are being developed.

${ }^{8}$ The interviews included 20 face to face interviews and 30 email interviews to renewable energy experts from the three main Ecuadorian cities.
}

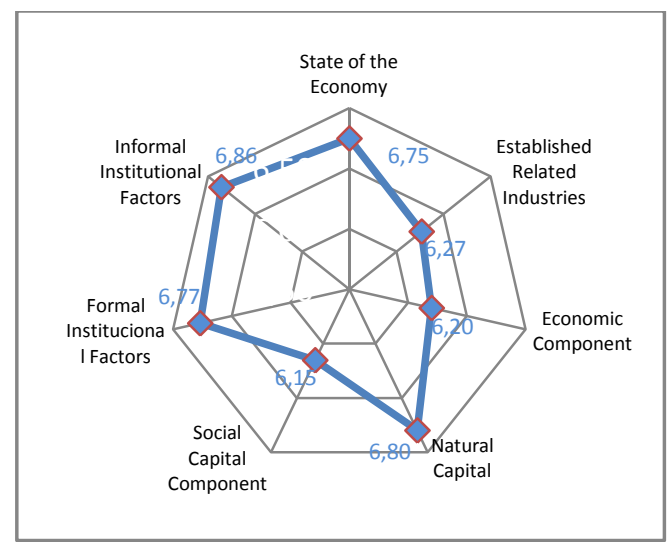

Fig. 2. Importance of the 7 factors that explain the start-up of a RE industry in Ecuador ([16])

In addition, the experts were asked to rank (and justify) the main formal institutional factors (policies) working to promote the renewable energy (wind power) development in Ecuador. Figure 3 shows that Regulation No. CONELEC ${ }^{9}$ 004/11, related to a feed-in tariff policy, scored as the most effective policy when it comes to promoting renewable energy development.

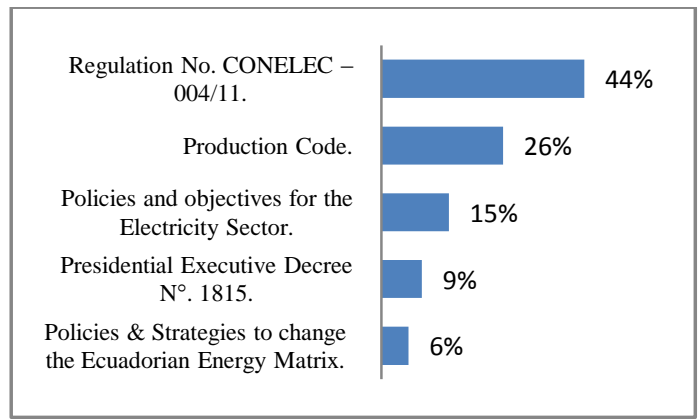

Fig. 3. Importance of the current RE policies in Ecuador ([16]).

The reasoning behind this ranking of specific RE policies can be summarized as follows ${ }^{10}$ :

- CONELEC-004/11: This policy provides preferential payment to non-conventional renewable energy technologies, thus facilitating confidence and cash-flow.

- PRODUCTION CODE: It can attract both foreign and private investment.

- SPECIFIC POLICIES: these policies establish clear objectives for the Ecuadorian power sector.

\footnotetext{
9 CONELEC (National Council of Electricity) is the Ecuadorian authority of the electricity sector.

${ }^{10}$ For more details see Annex 1.
} 
- EXECUTIVE DECREE 1815: This decree establishes that the projects' additionality (Kyoto's CDM) must facilitate the investment closing of a renewable energy project.

- POLICIES TO CHANGE THE ENERGY MATRIX: These policies establish clear objectives for periodical evaluation.

\section{Policy Effectiveness}

Since Regulation CONELEC 004/11 seems to be the most important policy for developing renewable energies in Ecuador, the authors analyzed the potential impact of such a regulation.

CONELEC's Regulation ([17]) guarantees two important aspects for RE producers: a fixed price per source for a time period (15 years) and preferential access to the grid. In order to enjoy these benefits, energy producers (both public and private) must have registered their projects with CONELEC before December $31^{\text {st }} 2012$.

The Regulation applies until the total installed capacity from renewables reaches $6 \%$ of the total installed capacity in the National Interconnected System. Since the total installed capacity was 4,742 MW (by December $31^{\text {st }} 2012$ ) this means a renewable energy quota of $284.5 \mathrm{MW}$.

Annex 2 shows the preferential prices established by CONELEC 004/11. Figure 4 summarizes information regarding projects that applied to CONELEC's Regulation.

\begin{tabular}{|c|c|c|c|}
\hline \multicolumn{4}{|c|}{$\begin{array}{l}\text { NON-CONVENTIONAL RENEWABLE ENERGY PROJECTS THAT APPLLED TO REGULATION CONELEC } \\
\text { O04/11 (DECEMBER 2012) }\end{array}$} \\
\hline $\begin{array}{c}\text { NUMBER OF } \\
\text { PROJECTS }\end{array}$ & TECNOLOGY & POWER CAPACITY (MW) & $\begin{array}{c}\text { INSTALLED CAPACITY } \\
\text { (MW)* }\end{array}$ \\
\hline 2 & BIOGAS & 15,7 & 0 \\
\hline 17 & PHOTOVOLTAIC (>1 MW) & 282 & $\left.0{ }^{* * *}\right)$ \\
\hline 78 & PHOTOVOLTAIC <1MW) & 76,4 & 0 \\
\hline 11 & HYDROPOWER (<50 MW) & 280 & 141,5 \\
\hline 3 & WIND POWER & 18,5 & 16,5 \\
\hline TOTAL & & 672,6 & 158 \\
\hline \multicolumn{2}{|c|}{$\begin{array}{c}\text { RENEWABLE PENETRATION BASED ON REGULATION (6\% } \\
\text { of total installed capacity in the Ecuadorian SNI) }\end{array}$} & $236 \%$ & $56 \%$ \\
\hline
\end{tabular}

$\left({ }^{*}\right.$ I t includes both operating projects and projects under construction as December 31/2012 $\left({ }^{* *}\right)$ A 50 MW photovoltaic plant is expected to start its construction in April 2013

Fig. 4. Non-conventional Renewable Energy Projects that applied to Regulation CONELEC 004/11.

Although it might be too soon to assess the Regulation's effectiveness (the ability to increase the renewable energy penetration in the National
Interconnected System) it is clear that there are already positive signs of success. According to CONELEC's Electricity Master Plan, it is expected that before 2020 the initial renewable energy quota (284.5 MW) will have been accomplished.

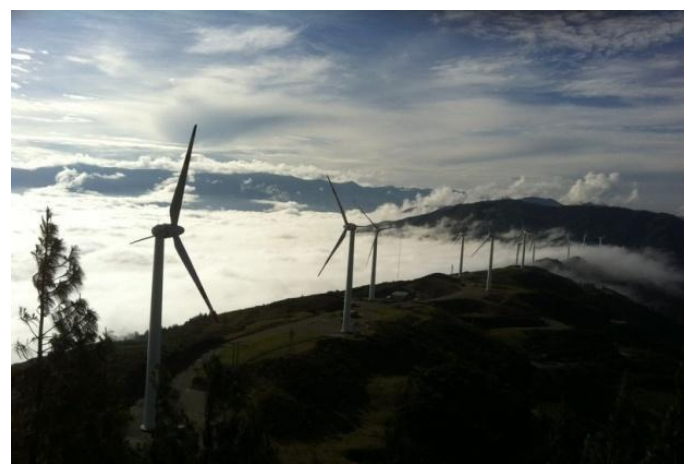

Fig. 5. Villonaco wind farm $-16.5 \mathrm{MW}$ at $2.700 \mathrm{~m}$ of altitude (Courtesy: CELEC EP- GENSUR)

\section{Conclusions and Main Contributions}

To develop renewable energies quickly, government intervention (e.g., policies) is needed to overcome the market and institutional barriers imposed by the conventional energy structure. Renewable energy legitimacy is necessary to level the playing field in the energy sector. Today, governments from developing countries are supporting the start-up of renewable energy industries as shown in the country-case presented in this paper.

Nevertheless, it seems that the implementation of energy policies is contingent on the specific context of countries and regions. The success of any RE policy should consider several variables (technological, economic, and institutional) present in any particular country.

In his research, Barragán (2012) extended Espinoza and Vredenburg's model. The interviews conducted showed that formal institutional factors are key elements to promoting the development of renewables, particularly wind power. In the Ecuadorian case, regulation CONELEC 004/11 (a feed-in tariff approach) scored the highest amongst current energy policies. This policy seeks to guarantee two aspects for RE producers: a fixed price per source for a 15 year-period, and fair access to the grid.

The feed-in tariff approach seems a necessary but not sufficient condition to promote 
renewables. There are additional policies that contribute to this development as shown in the Ecuadorian case.

This study makes contributions to institutional and strategic change theories by showing the role of formal institutional factors (i.e. policies) as sources of industry legitimacy for renewable energies in a developing country. The Ecuadorian case has important implications for policy makers and energy managers because it shows how a RE industry can be developed in a regulated electricity market.

\section{References}

[1] Elliott, D. (2000). Renewable energy and sustainable future. Futures, 32: 261-274

[2] Espinoza and Vredenburg (2010). Towards a model of wind energy industry development in industrial and emerging economies. Global Business and Economics Review, 12( 3): 203-229

[3] Aldrich, H. and Fiol, C.M. (1994) Fools in rush? The institutional context of industry creation, Academy of Management Review, Vol. 19, No. 4, pp.645-760.

[4] DiMaggio, P. and Powell, W. (1983) The iron cage revisited: institutional isomorphism and collective rationality in the organizational field, American Sociological Review, Vol. 48, pp.147-160.

[5] Suchman, M.C. (1995) Managing legitimacy: strategic and institutional approaches, Academy of Management Review, Vol. 20, No. 3, pp.571-610.
[6] Ayres, R. (2001) How economists have misjudged global warming, World Watch Magazine, SeptemberOctober, Vol. 14, No. 5, pp.12-25.

[7] RETScreen (2012) Clean Energy Policy Toolkit (http://www.retscreen.net)

[8] Rader, N. and R. Norgaard (1996). Efficiency and sustainability in restructured electricity markets. The Electricity Journal July.

[9] Mirasgesdis, S., D. Diakoulaki, et al. (2000). Impact of social costing on the competitiveness of renewable energy: case of Crete. Energy Policy 28: 65-73.

[10] Torres López, M. y Arana García, E. (2010). Energía eólica: Cuestiones jurídicas, económicas y ambientales. Civitas, THOMSON REUTERS: 29-35.

[11] Brower, M. (1994). Cool Energy. Massachusetts, Massachusetts Institute of Technology - MIT.

[12] Suarez, F. and J. Utterback (1995). Dominant designs and the survival of firms. Strategic Management Journal, 16: 415-430.

[13] Freeman, C. and L. Soete (1997). The Economics of Industrial Innovation. Cambridge, MA, MIT Press.

[14] Komor, P. (2004). Renewable Energy Policy. Diebold Institute for Public Policy Studies, N.Y.

[15] Asmus, P. (2000). Trends in the wind: lessons from Europe and the US in the development of wind power. Corporate Environmental Strategy, 7: 51-61.

[16] Barragán, E. (2012). Análisis, especificación y desarrollo de los procedimientos de operación para la gestión de la energía eólica en Ecuador. Unpublished M.Sc. thesis, Universidad de Cuenca, Ecuador.

[17] Consejo Nacional de Electricidad (2011), Regulación No. CONELEC - 004/11 "Tratamiento para la energía producida con Recursos Energéticos Renovables No Convencionales". 


\section{ANNEX 1: Renewable Energy Policies implemented in Ecuador.}

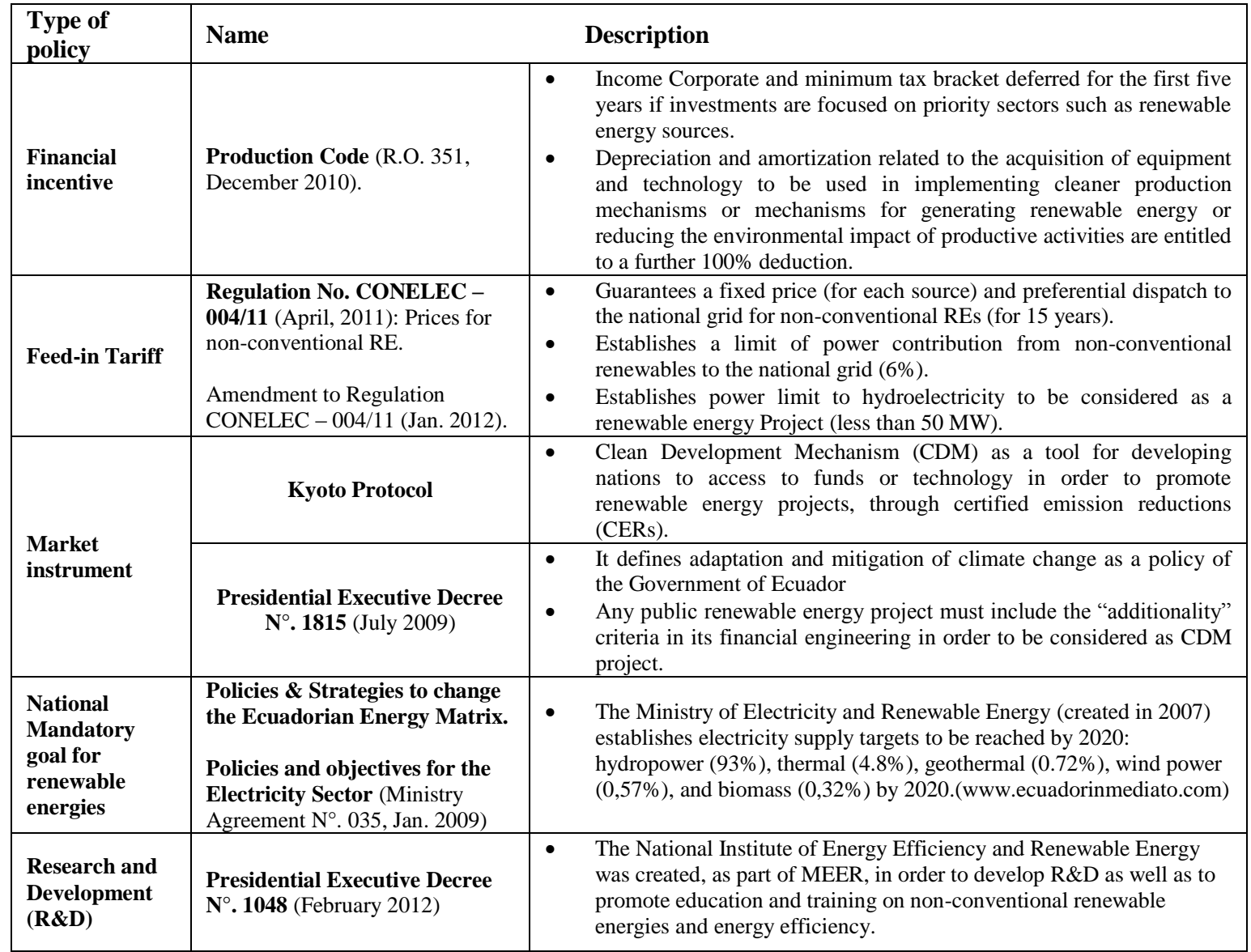

\section{ANNEX 2: Prices for Renewable Energy Sources (Regulation CONELEC 004/11)}

Preferential Prices (USD cents/kWh) for Renewable Energy sources (except Hydropower)

\begin{tabular}{|l|c|c|}
\hline \multicolumn{1}{|c|}{ SOURCE } & $\begin{array}{c}\text { PRICE ON ECUADORIAN } \\
\text { CONTINENT }\end{array}$ & $\begin{array}{c}\text { PRICE ON GALAPAGOS } \\
\text { ISLANDS }\end{array}$ \\
\hline WIND POWER & 9.13 & 10.04 \\
\hline PHOTOVOLTAIC & 40.03 & 44.03 \\
\hline TERMO-SOLAR & 31.02 & 34.12 \\
\hline CORRIENTES MARINAS & 44.77 & 49.25 \\
\hline BIOMASS and BIOGAS $<$ 5 MW & 11.05 & 12.16 \\
\hline BIOMASS and BIOGÁS > 5 MW & 9.60 & 10.56 \\
\hline GEOTERMAL & 13.21 & 14.53 \\
\hline
\end{tabular}

Preferential Prices (USD cents/kWh) for Hydropower plants under $50 \mathrm{MW}$

\begin{tabular}{|l|c|}
\hline \multicolumn{1}{|c|}{ PLANT } & PRICE \\
\hline HYDROPOWER (<10 MW) & 7.17 \\
\hline HYDROPOWER (10 MW to 30 MW) & 6.88 \\
\hline HYDROPOWER (30 MW to 50 MW) & 6.21 \\
\hline
\end{tabular}

